\title{
Evaluation of Facies Architecture and Depositional Environment of G-Field in the Greater Ughelli Depobelt of the Niger Delta Area, Nigeria
}

\author{
*OKENGWU, K. O; SORONNADI-ONONIWU, GC \\ Department of Geology, University of Port Harcourt, PMB 5323, Port Harcourt, Nigeria \\ *Corresponding Author; Email: kingsley.okengwu@uniport.edu.ng; Tel: +2348036671300
}

\begin{abstract}
This study utilized well logs and core data to evaluate facies architecture and depositional environment of G-field in the Greater Ughelli Depobelt of the Niger Delta area in Nigeria. The study revealed five lithofacies unites, namely, Bioturbated Sandstone Facies (BSF), Coarse to Pebbly Sandstone Facies (CPSF), Mudsone Facies (MF), Very Fine Grained laminated Sandstone Facies (FGLSF), and Wavy- to Flaser-Bedded Facies (WFbF). The lithofacies were grouped into Two (2) Facies Assemblages that where established from the five mentioned lithofacies A-E. The Facies Assemblages are Open-marine Facies Association, Brackish-water Marginal-marine Facies Association and Tidal Flat Association. Gamma Ray (GR) logs within the cored interval defined an aggrading deposit. These assemblages were used to infer the various environments responsible for the deposition.
\end{abstract}

\section{DOI:https://dx.doi.org/10.4314/jasem.v25i10.2}

Copyright: Copyright $@ 2021$ Okengwu and Soronnadi-Ononiwu. This is an open access article distributed under the Creative Commons Attribution License (CCL), which permits unrestricted use, distribution, and reproduction in any medium, provided the original work is properly cited.

Dates: Received: 22 August 2021; Revised: 17 September 2021; Accepted: 06 October 2021

Keywords: Assemblages, Brackish, Depositional Environments, Lithofacies, Open-marine, Sandstone.

A depositional sedimentary environment is a geomorphic setting in which sediment accumulates. Such a setting is characterised by a unique set of physical, biological and chemical processes operating at specified rates and intensities that impart sufficient imprint on the sediment to produce a characteristic deposit. The character of the sediment so produced is determined by the intensities of the formative processes operating to produce it and by the duration through which such action is continued. Thus deposition in a given environmental setting produces a sedimentary facies characteristic of that specific environment. The Niger delta is an example of a mixed wave, tide and fluvial deltaic system. It has long been recognised as deposits within the Miocene Agbada Formation of the Niger Delta Petroleum system, and it represent a prograding fluvial-deltaic depositional system with intercalation of marine mudstone. Sandstone units within the formation consist of fluvial (channel) or fluvio-marine (barrier bar), tidal channel and shoreface facies. Mineralogically, the sandstone of Agbada Formation consist of high percentage of quartz, less feldspar, and traces of glauconite and zircon. Mudstones are generally fluvio-marine or lagoonal facies. The clay minerals are mainly mixtures of kaolinite, smectite and illites with some traces of pyrite, feldspar and carbonate. The thickness of the reservoir intervals in some fields ranges from 45 feet to 150 feet. Most of the reservoirs observed within the shallow marine paralic section have been described as point bars of a distributary channels, tidal channel fills, coastal barrier bars and shoreface deposits (Weber, 1971). Sediments in different paleoenvironments display characteristic log motifs. Hence, borehole logs are widely used to interpret sedimentary facies (Weber, 1971). Information about the sediments and sedimentary processes from the logs are usually not sufficient alone, due to some lithologies having similar natural radioactivity and electrical properties. Information from cuttings and cores is therefore often an essential component of any lithologic analysis. The combination of core description and wireline log data makes it much more possible to generate a series of (wireline) log facies. The log facies may then be used to describe the reservoir section in uncored, but logged wells (Gluyas and Swarbrick, 2004). Therefore, the present study examined well logs and core data to evaluate facies architecture and depositional environment of G-field in the Greater Ughelli Depobelt of the Niger Delta area in Nigeria.

\section{MATERIALS AND METHODS}

Description of Study Area: The study area, "G Field" is located within the Greater Ughelli Depobelt. It lies between longitude $5.14^{\circ} \mathrm{E}$ and $5.28^{\circ} \mathrm{E}$ and latitude $5.14^{\circ} \mathrm{N}$ and $5.26^{\circ} \mathrm{N}$ (Figure 1) on the onshore part of the Northwest Niger Delta. There are six wells in the field (Figure 2). The lithostratigraphy of the Tertiary Niger Delta is divided into three major units: Akata, Agbada and Benin formations, with depositional environments ranging from marine, transitional and continental settings respectively. (Figure. 3 and Table 1). The Akata, Agbada and Benin formations overlie stretched continental and oceanic crusts (Heinio and Davies, 2006). Their ages range from Eocene to Recent, but they transgress time boundaries. These prograding depositional facies can be distinguished mainly on the basis of their sand-shale ratios. 


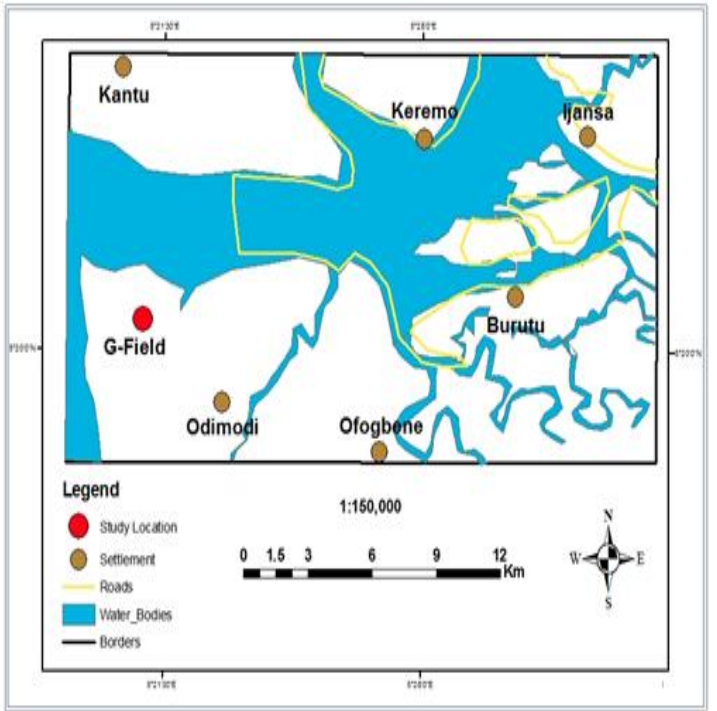

Fig 1: Map showing location of study area

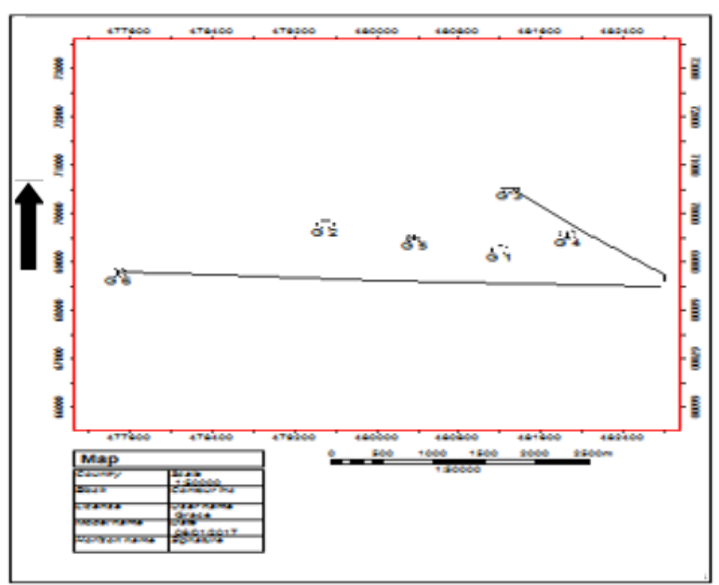

Fig. 2: Base map with location of the six wells in the study area.

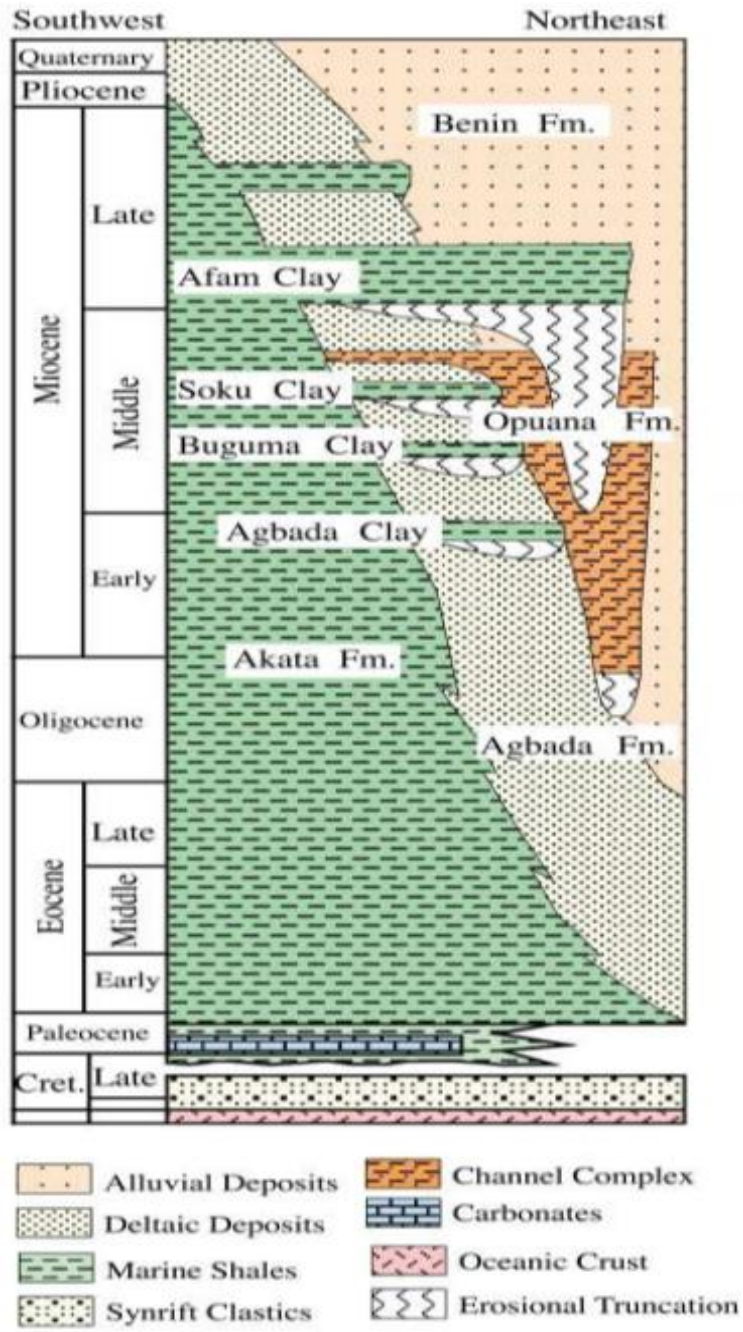

Fig. 3: Stratigraphic column showing the three formations of the Niger Delta (modified from Lawrence et al, 2002).

Table 1: Formations Niger Delta area. Modified from Short and Stauble (1967)

\begin{tabular}{|c|c|c|c|c|c|}
\hline $\begin{array}{l}\text { Subsurface } \\
\text { Youngest } \\
\text { Known } \\
\text { Age }\end{array}$ & & $\begin{array}{l}\text { Oldest } \\
\text { Known } \\
\text { Age }\end{array}$ & $\begin{array}{l}\text { Surface Outcrops } \\
\text { Youngest Known } \\
\text { Age }\end{array}$ & & $\begin{array}{l}\text { Oldest } \\
\text { Known } \\
\text { Age }\end{array}$ \\
\hline Recent & $\begin{array}{l}\text { Benin } \\
\text { Lithostratigraphic } \\
\text { Unit, (Afam Clay } \\
\text { Member) }\end{array}$ & Oligocene & Plio./Pleistocene & Benin Formation & \\
\hline Recent & $\begin{array}{l}\text { Agbada } \\
\text { Lithostratigraphic } \\
\text { Unit }\end{array}$ & Eocene & $\begin{array}{l}\text { Miocene } \\
\text { Recent }\end{array}$ & $\begin{array}{l}\text { Agwashi } \\
\text { Asaba } \\
\text { Formation, Ameki } \\
\text { Formation }\end{array}$ & $\begin{array}{l}\text { Oligocene } \\
\text { Eocene }\end{array}$ \\
\hline Recent & $\begin{array}{l}\text { Akata } \\
\text { Lithostratigraphic } \\
\text { Unit }\end{array}$ & Eocene & Lower Eocene & $\begin{array}{l}\text { Imo Shale } \\
\text { Formation }\end{array}$ & Paleocene \\
\hline Unknown & & & $\begin{array}{l}\text { Paleocene } \\
\text { Maestrichtian } \\
\text { Campanian } \\
\text { Canpanian/Maestrichtian } \\
\text { Coniacian/Santonian } \\
\text { Turonian } \\
\text { Albian }\end{array}$ & $\begin{array}{l}\text { Nsukka, Formation } \\
\text { Ajali, Formation } \\
\text { Mamu, Formation } \\
\text { Nkporo, Shale } \\
\text { Agwu, Shale, Eze } \\
\text { Akwu, Shale } \\
\text { Asu River, Group }\end{array}$ & $\begin{array}{l}\text { Maestrichtian } \\
\text { Maestrichtina } \\
\text { Campanian } \\
\text { Santonian } \\
\text { Turonian } \\
\text { Turonian } \\
\text { Albian }\end{array}$ \\
\hline
\end{tabular}

Niger Delta depositional belts or "depobelts" consists of a series of off-lapping siliciclastic sedimentation cycles or mega-sedimentary belts. Evamy et al (1978) referred to this structure as, "mega structure" while
Doust and Omatsola (1990) were the first to call them "depobelts". Five regional depobelts were identified along the north - south axis of the delta, each with its own sedimentation, deformation and petroleum 
history. These depobelts include: the Northern Delta, the Greater Ughelli, the Central Swamp I \& II, the Coastal Swamp and the offshore depobelts. (Figure 4). Each of these depobelts is bounded by large-scale regional and counter-regional growth faults (Evamy et al, 1978; Doust and Omatsola, 1990; Pochat et al, 2004). The activity in each belt has progressed in time and space toward the south-southwest through stepwise alluvial progradation facilitated by largescale withdrawal and forward movement of the underlying shale. The interplay of subsidence and supply rates resulted in deposition of discrete depobelts - when further crustal subsidence of the basin could no longer be accommodated, the focus of sediment deposition shifted seaward, forming a new depobelt (Doust and Omatsola, 1990). Several authors have worked on studies of depositional environment in Niger Delta, amongst them are Keele and Evans, (2008); Arochukwu, (2014); Fitch et al., (2014), in their works, they stated that environments of deposition of sedimentary rocks play significant role in controlling the geometries of geobodies, architecture, grain-to-grain arrangement of framework particles and the accumulation of fluids within the pores of the rock.



Fig 4: Niger Delta Depobelts and Niger Delta Regional crosssection; Showing structural belts. (Adopted from Hooper et al. 2002).
Slatt, (2006) stated that modern and ancient sedimentary environments can be identified from subsurface cores and outcrops using distinct sedimentary structures. Snedden and Bergman, (1999); Slatt, (2006) were of the opinion that each environment where sediments are deposited is unique in its physical and chemical characteristics and represents the processes that formed the environment. According to Rider, (1996), Lithofacies can be distinguished in cores but cannot always be distinguished from logs because the resolution of the logs (minimum 2ft) does not allow subtle difference between some lithofacies types. Oomken (1974) in his study, examined the sediments in the Terrestrial and Submarine parts of the modern delta and grouped them into three major lithofacies using lithological characteristics and other sedimentary features. These lithofacies are grouped into sandstone, heteroliths and mudstone. This research methodology in this study involved delineation of lithologies, correlation of sand units, identification of electrofacies, lithofacies, and facie assemblages and then paleoenvironmental reconstruction (Figure 5 shows the direct correlation between facies and $\log$ shapes). Core data were described and interpreted from bottom upwards using the lithofacies classification scheme. (Table 2).
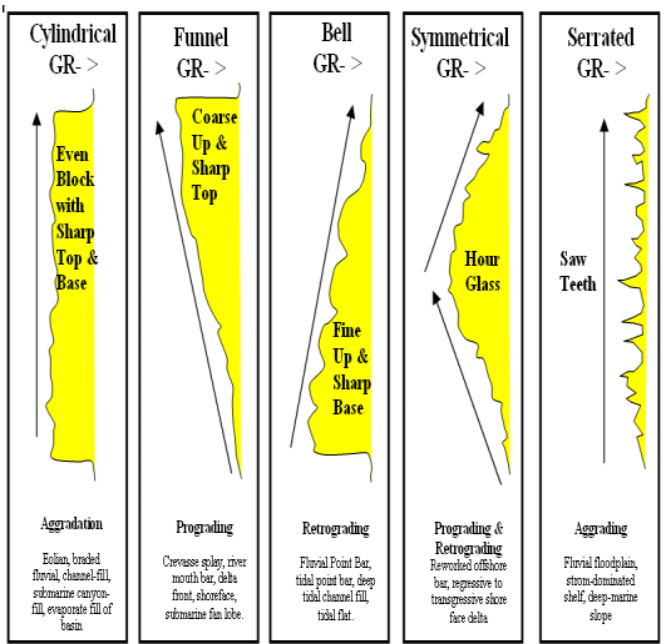

Fig 5: The direct correlation between facies and a variety of other log shapes relative to the sedimentological relationship (Cant, 1992)

Table 2: Tabulated Lithofacies Scheme (after S.P.D.C, Nigeria)

\begin{tabular}{|c|c|c|}
\hline Dominant Grain Size & $\begin{array}{l}\text { Dominant } \\
\text { Sedimentary Structure }\end{array}$ & $\begin{array}{l}\text { Secondary } \\
\text { Sedimentary } \\
\text { Structure }\end{array}$ \\
\hline $\begin{array}{c}\text { (sandstone) } \mathrm{C}-\text { coarse } \\
\mathrm{M}-\text { medium } \\
\mathrm{F}-\text { fine }\end{array}$ & $\begin{array}{l}\text { M (massive) } \\
X \text { (cross-bedded) } \\
\mathrm{P} \text { (planar, parallel bedded })\end{array}$ & $\begin{array}{l}\mathrm{C} \text { (cement- } \\
\text { general) }\end{array}$ \\
\hline $\begin{array}{l}<90 \% \text { sand } \\
\text { S(sandstone }\end{array}$ & $\begin{array}{l}\mathrm{H} \text { (hummocky-swaley cross-bedded) } \\
\text { W (wave rippled) } \\
\mathrm{C} \text { (current rippled) }\end{array}$ & $\mathrm{S}$ (siderite) \\
\hline $\begin{aligned} & \mathrm{H} \text { (heterolithic) }> 50 \% \text { sand } \\
&>50 \% \text { mud } \\
& \mathrm{M} \text { (mudstone } \\
& \text { dominant) }\end{aligned}$ & $\begin{array}{l}\mathrm{B} \text { (bioturbated) } \\
\mathrm{R} \text { (rooted) } \\
\mathrm{F} \text { (fossiliferous) } \\
\mathrm{O} \text { (organic-carbonaceous) }\end{array}$ & $\begin{array}{l}\text { sediment } \\
\text { deformed - } \\
\text { slumped, } \\
\text { slide, micro }\end{array}$ \\
\hline $\begin{array}{l}>90 \% \text { mud } \\
\text { M (mudstone) } \\
\mathrm{C} \text { (coal) }\end{array}$ & & faulted \\
\hline
\end{tabular}




\section{RESULT AND DISCUSSION}

Lithofacies and Interpretation: Five lithofacies were recognised on the basis of lithology and sedimentary structures. Interpretation follows each described lithofacie. Some lithofacies were repeated within the section while a few others occur at different positions.

Lithofacies A: Bioturbated Sandstone Facies (BSF): The lithofacies is fine to medium grained, moderately to well-sorted and greyish brown in colour. Intensely bioturbated. Has some thin undisturbed intervals showing fine inorganic structures. (Figure 6)

Interpretation: Bioturbation indicates low energy conditions, with high oxygen content due to shallow depth, and abundance of nutrient within the substrate and slower rate of deposition. An alternation of bioturbated intervals with intervals showing fine inorganic structures indicates periodic rapid deposition of thick interval which burrowers are unable to penetrate. Typical environment is tidal flat.

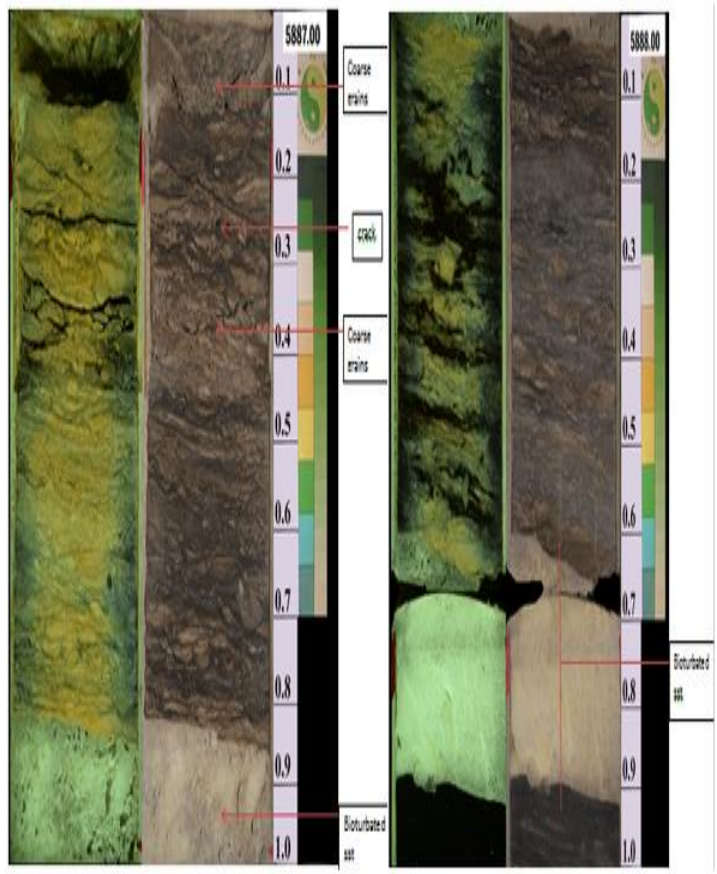

Fig 6: Facies A, Bioturbated Sandstone

Lithofacies B: Coarse to Pebbly Sandstone Facies $(C P S F)$ : The lithofacie type is very poorly sorted, the pebbles are very angular to sub angular. Some sideritic concretions observed at the bottom. It appears massive in most cases with occasional ripple cross lamination and is moderately bioturbated. (Figure 7)

Interpretation: The coarse grained character and the angularity of the grains indicate short distance of travel and low basinal processes. The very poor sorting and massive nature suggests deposit of episodic flooding, too concentrated to be mobilized by basinal processes. Typical environment is lag deposits.

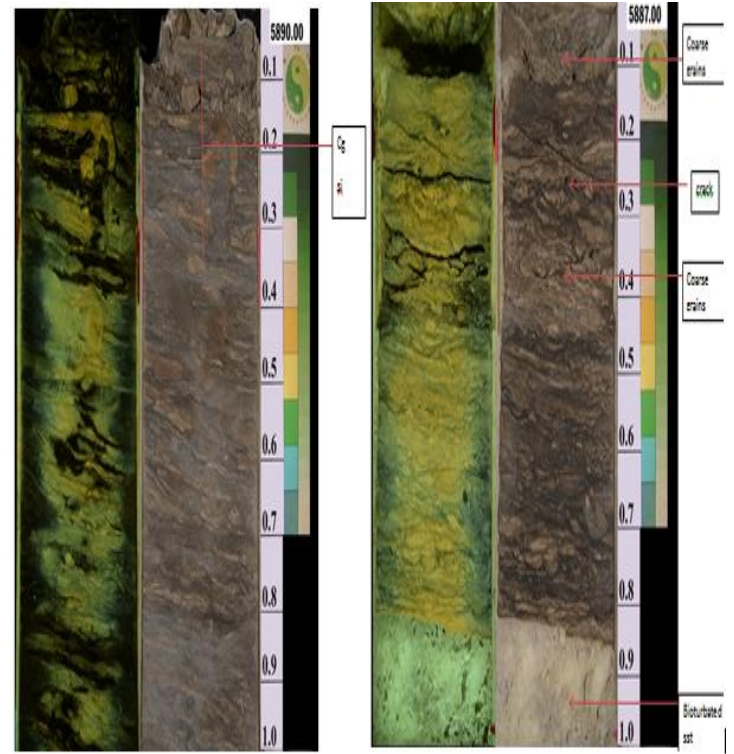

Fig 7: Facies B, Coarse to pebbly sandstone

Lithofacies $C$ : Mudstone $(M F)$ : It consists of darkgreenish-gray mudstone with parallel silt laminae. This facies is characterized by thin elongate, diagenetic siderite nodules. Planar lamination is also observed. Bioturbation in this facies is slight to rare. (Figure 8).

Interpretation: The sediment of the mudstone facies was probably deposited under quiet and low energy conditions, allowing for shale lamination. The sections with silty laminae are indicative of the intrusion of a more energetic event. Preservation of thin laminations, absence of bioturbation, and dark colours are suggestive of anoxic and reducing bottom-water conditions. Walker and Plint (1992) and Reineck and Singh (1980) described mudstones as offshore or shelf deposits. The mudstone unit with silty laminae is interpreted to have been deposited in an overbank of a channel while the black/dark laminated mudstone is interpreted to have been deposited in shelf environment.

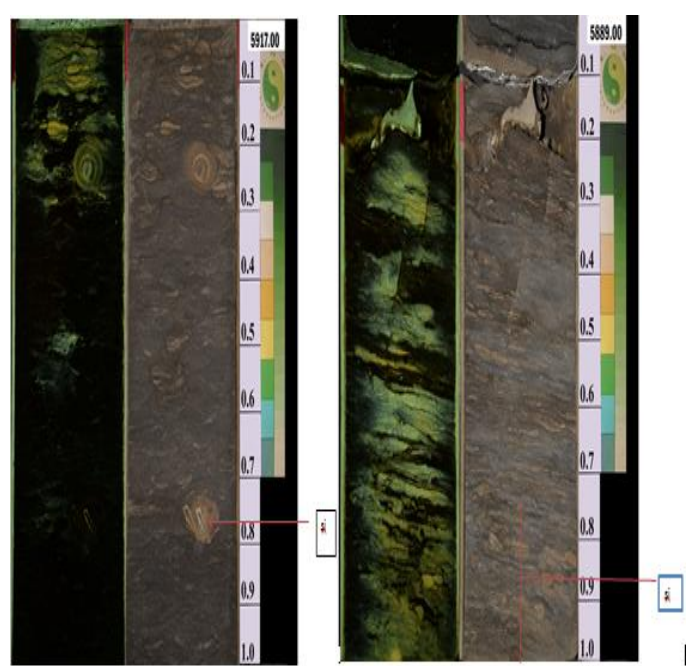

Fig 8: Facies C Mudstone 
Lithofacies D: Very Fine Grained laminated Sandstone Facies (FGLSF): Greater than $80 \%$ shale and silty shale with dark grey colouration. Very slightly bioturbated and characterized by well-defined parallel and horizontal laminations (Figure 9)

Interpretation: The lamination and very fine grain size of this facies indicate Suspension deposits, overbank or abandoned channel associated with low energy condition. The dark grey colouration indicates high organic matter.



Fig 9: Very Fine Grained laminated Sandstone Facies (FGLSF)

Facie E: Wavy-to Flaser-Bedded (WFbF): The facies consist of light grey, wavy- to flaser-bedded, very finegrained sandstone with mudstone drapes, and wave and current ripple cross-lamination are common. Bioturbation is absent to very sparse. (Figure 10).

Interpretation: The wavy- to flaser-bedded nature indicates a setting characterized by relatively lower energy. The presence of mud drapes indicates tidal influence. It represents tidal influenced sedimentation in a brackish-water environment, most likely a bay margin (MacEachern and Gingras, 2007; Angulo and Bautois, 2012).

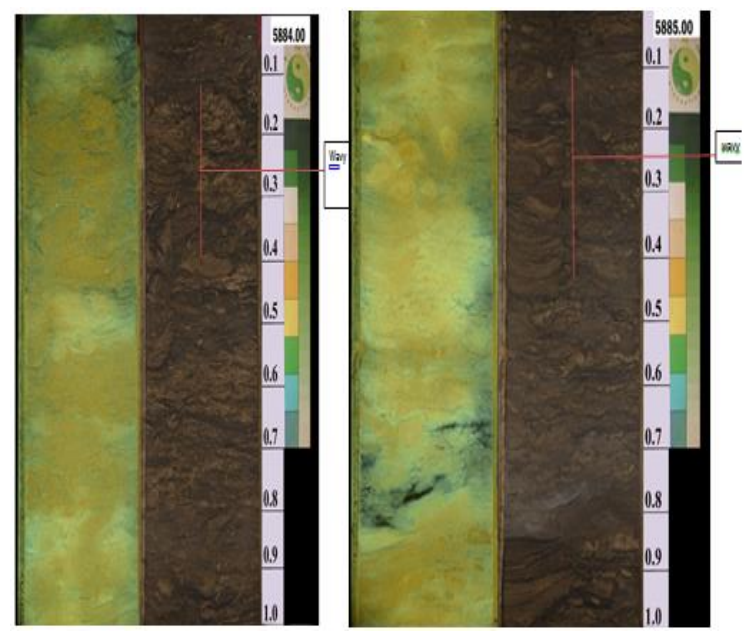

Fig 10: Facies E, Wavy- to Flaser-bedded.
Facies Association and Interpretation: Facies associations are groups of facies that occur together and are considered to be genetically or environmentally related (Reading, 1996). Hence the associations are related to a range of energy level within an environment of deposition. The nature of $\log$ data resolution, makes it is necessary to carry out some grouping of facies association in order to get a consistent match with logs and the core data. The Lithofacies described from well are usually described in terms of lithology, grading feature, sedimentary structure, and then lithofacies association are interpreted in terms of depositional environment. Therefore interpreting a facies is in reference to its neighbour. It is a reflection of the combination of processes and environment of deposition, resulting from the co-occurrence of a set of lithofacies arranged in a particular order. The log signature suggests an aggrading environment as it is serrated-saw teeth. Hence implying it is either of the following environments, fluvial floodplain, storm-dominated shelf and deep marine slope. Log interpretation was used to infer the environment of deposition of the cored interval and consolidated with the core interpretation results, as shown in Figure 11.

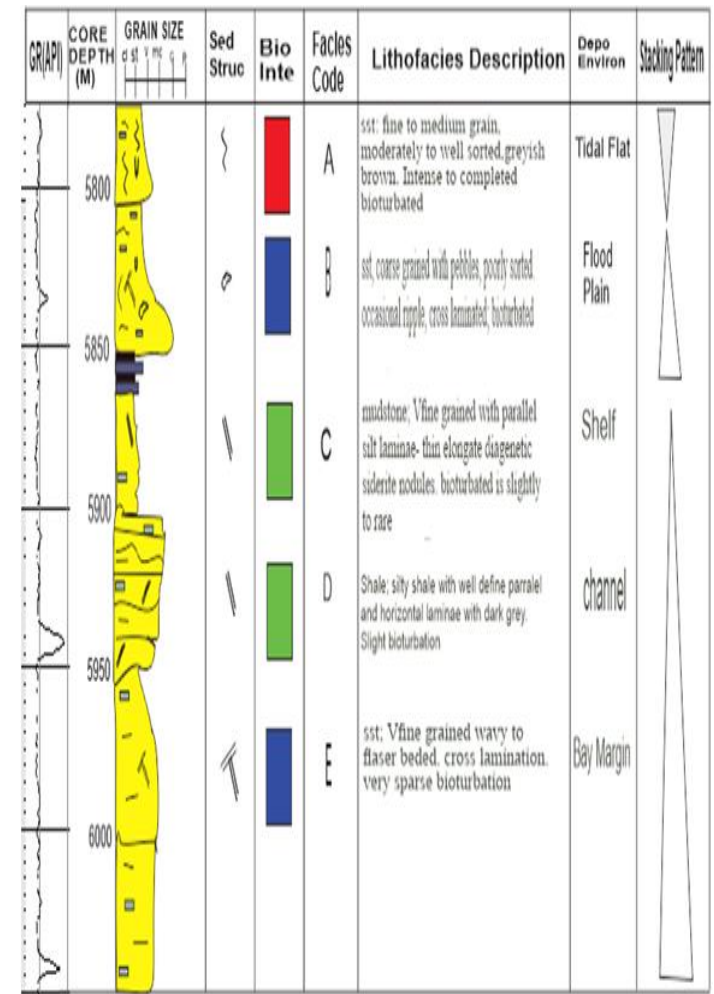

Fig 11: Depositional Environments Litholog of the Cored Section of G-Field

1) Open-Marine Facies Association: It is an area of low energy so it consist of fine grained sand interspersed with thin layers of mud, moderate to intense bioturbation and burrowing. The lithofacies is dominantly muddy and shaly due to the prevalence of low energy condition in lower shoreface. These environments vary from higher energy nearshore (and 
sandy sediment) to quieter water offshore (and clays). These sediments have the potential for being the source rock for petroleum.

The open-marine facies association contains two of the facies identified in this study (Facies C, D), representing different subenvironments located along the depositional profile of a low-energy, waveinfluenced, shallow-marine setting. The shale (Facies D) represents a shelf environment. The mudstone (Facies C) records deposition in a lower-offshore environment. Generally, the open-marine environment is characterized by the distal Cruziana ichnofacies.

2) Brackish-Water Marginal-Marine Facies Association: The Marginal Marine is located around the boundary between the continental and the marine depositional realms. The Marginal Marine is dominated by wave, river and tidal processes. The characteristics of Marginal Marine are high-energy waves and currents, although some lagoonal and estuarine environments are dominated by quiet-water conditions. The depositional settings in marginal marine sediment are delta, beach, and Barrier Island, estuarine, lagoonal, and tidal flat.

The brackish-water marginal-marine facies association contains three of the facies identified in this study (Facies A, B and E), representing different subenvironments of a restricted embayment with limited or intermittent connection to the open-marine environment. The bioturbated fine sandstone, (Facies A) represent a tidal flat and wavy- to flaser-bedded, very fine-grained sandstone (Facies E), record a bay margin environment; and the pebbly sandstone (Facies B) suggests episodic flooding. Heterolithic lamination/bedding, mudstone drapes, syneresis cracks, and low bioturbation in these facies all suggest tidal influenced and stressful marginal-marine environments instead of open-marine environments. Compared to the open-marine environment, strata deposited in the brackish-water marginal-marine environment generally display a lower bioturbation index, smaller size of trace fossils and also a lower ichno diversity and abundance of trace fossils. The marginal-marine environment is usually characterized by the depauperate Cruziana ichnofacies.

3) Tidal Flat: The Tidal Flat is transition environment that is affected by tide. The tidal flat is divided into 3 zones, supratidal, intertidal, and subtidal.

- $\quad$ Supratidal Zone, the zone is influenced by extreme tides. This zone will evaporate and produce crystal salt. This zone is also called Sabkha.

- Intertidal Zone, located on between high and low tide level. This zone occurs with the bedload and suspension load transportation.

- $\quad$ Subtidal Zone, is under the water, with low tide level. Tide influence in this environment is very important especially at tidal channels, where bedload transport and deposition are dominant. The facies A shows characteristics typical of the Subtidal Zone.

Depositional Model: The lithologies of the study area are broadly classified into sand and shale as shown from the well $\log$ and core samples (Figure 12 and Table 3). The Gamma Ray log has a shale reference line of 75 API, selected from the usual potential of 0150 API. Increasing gamma ray values to the right of the reference line indicates increasing shale/clay; on the other hand decreasing gamma ray to the left of the reference line indicates increasing sand percentage.

The method used entails recognizing patterns that show changing water depths and sediment distribution within a depositional unit. A saw teeth GR log within the cored interval defines the deposits as an aggrading depositional model (Figure 13).

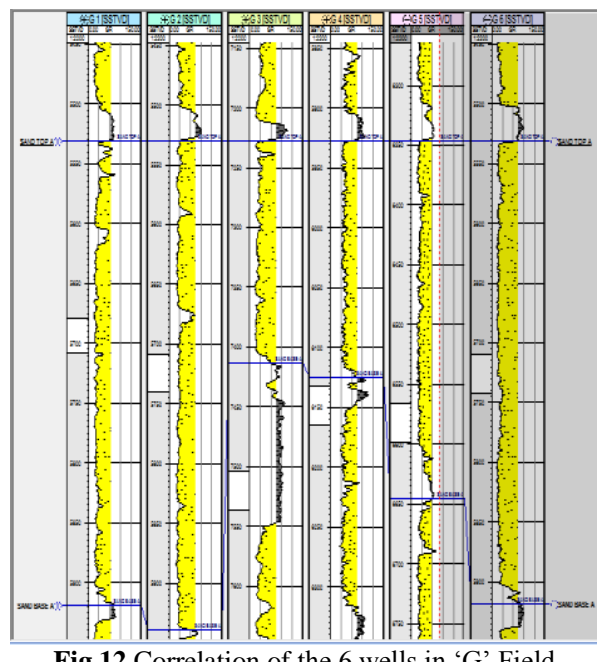

Fig 12 Correlation of the 6 wells in 'G' Field

\begin{tabular}{|c|c|c|}
\hline & WELLS & DEPTH \\
\hline & G1 Top & 5563 \\
\hline & G1 Base & 6322 \\
\hline & G2 Top & 5029 \\
\hline & G2 Base & 6330 \\
\hline & G3 Top & 7227 \\
\hline & G3 Base & 7417 \\
\hline & G4 Top & 5920 \\
\hline & G4 Base & 6123 \\
\hline & G5 Top & 6341 \\
\hline & G5 Base & 6640 \\
\hline & G6 Top & 5534 \\
\hline & G6 Base & 5917 \\
\hline
\end{tabular}

The ' $G$ field' is an onshore field located off northwest of the Niger delta in the Gulf of Guinea. The combination of core data from the cored well and gamma ray log responses was useful in generating a series of $\log$ facies. The $\log$ facies were used to describe the reservoir section in the uncored, but logged wells in the field. Five (5) Lithofacies A-E: Facies A; Bioturbated Fine Grained Sandstone. Facies B; Pebbly Sandstone. Facies C; Mudstone with Silt. Facies D; Very Fine Grained laminated Sandstone Facies and Facies E; Wavy to Flaser Fine Grained Sandstone were recognized in the study ares. The 
facies represents palaeo depositional environment of tidal flat, episodic flooding, shelf, channel and brackish water bay margin. The dominant lithologies in the wells are sand, silt and clay.

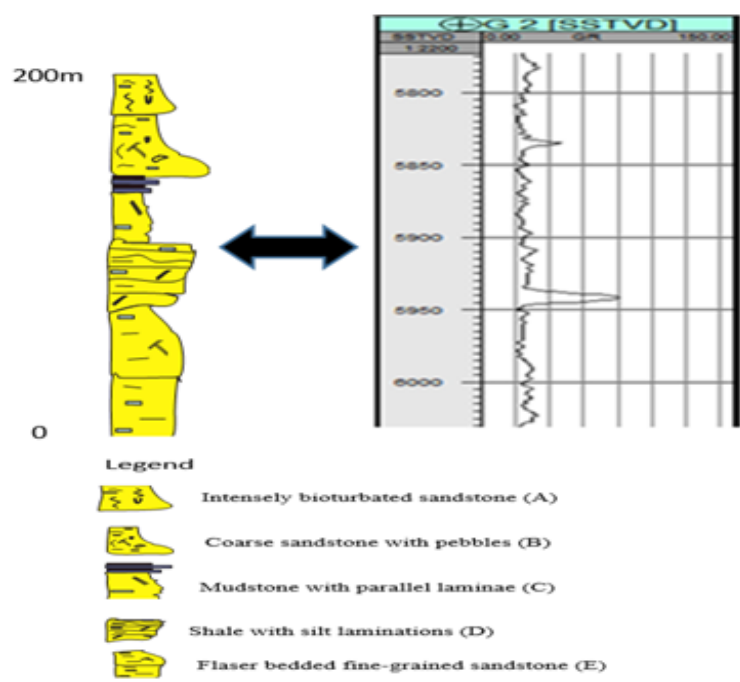

Fig 13: GR well G2 Log Showing Saw Teeth Signature at cored interval and model

From the facies assemblage three (3) depositional environments were identified. The Open Marine deposits, Brackish-water Marginal Marine deposits and Tidal Flat deposits. Among the 3 types of tidal flat, facies A showed characteristics, typical of the Subtidal Zone. A saw teeth GR log within the cored interval helped to defines the deposits of the study area as an aggrading depositional model.

Conclusion: This study established Five Lithofacies A-E: Facies A; Bioturbated Fine Grained Sandstone. Facies B; Pebbly Sandstone. Facies C; Mudstone with Silt. Facies D; Very Fine Grained laminated Sandstone Facies and Facies E; Wavy to Flaser Fine Grained Sandstone and three Facies Assemblages. The Facies Assemblage helped to infer the three depositional environments of Open Marine deposits, Brackishwater Marginal Marine deposits and Tidal Flat. A saw teeth GR $\log$ within the cored interval helped to defines the deposits of the study area as an aggrading depositional model.

\section{REFRENCES}

Allen, J.R.L. (1965). Late Quaternary Niger Delta, and adjacent Areas-Sedimentary Environments and Lithofacies: AAPG Bulletin, 49, 547-600.

Amajor, L.C. and Agbaire, D.W. (1989). Depositional history of the Reservoir Sandstones, Akpor and Apara Oilfields, Eastern Niger Delta, Nigeria. Jour. Pet. geol., 12, 453-464.

Angulo, S. and Buatois, L. (2012). Integrating Depositional Models, Ichnology, and Sequence Stratigraphy in Reservoir Characterization: the middle member of the Devonian-Carboniferous
Bakken Formation of subsurface Southeastern Saskatchewan revisited; AAPG Bulletin, 96, 1017-1043.

Arochukwu, E. (2014). Assessing the impact of Reservoir Architecture on secondary recovery: a case study of "century" field, Niger delta. Proceedings of the Nape monthly technical meeting, (mtm’ 14), Port Harcourt, Nigeria.

Cant, D.J. (1992). Subsurface Facies analysis. In: Walker, r.g. And n.p. James (eds.), Facies Models: response to Sea Level Changes. Geological Association of Canada, St., John's, NFLD 409, 09192-16498.

Dalrymple, R., Zaitlin, B.A and Boyd, R (1992). Classification of Clastic Coastal Depositional Environments 80, 139-150

Doust, H. (1989). The Niger Delta: Hydrocarbon Potential of a Major Tertiary Delta Province, in Coastal lowlands, Geology and Geotechnology, inproceedings of the kon. Nederl. Geol. Mijnb. Genootschap, 203-212

Doust, H. and Omatsola, E. (1989). Niger Delta: American Association of Petroleum Geologists Memoir 48, 201-238

Doust, H., and Omatsola, E. (1990). Niger Delta, in, Edwards, J. D., and Santogrossi, P.a., eds., divergent/passive margin basins. AAPG, 239-248

Ejedawe, J.E. (1981). Patterns of incidence of oil reserves in Niger Delta basin $A A P G, 65,1574-$ 1585

Evamy, B.D., Haremboure, J., Kamerling, P., Knaap, W.A., Molloy, F.A., and Rowlands, P.H. (1978). Hydrocarbon habitat of tertiary Niger delta. $A A P G$, Bulletin, 62, 1-39.

Fidelis A. Ushie \& Thomas H (2014). The Petrophysical Evaluation and Depositional Environment of Harrison 1 well using core data and Wireline Logs. Jour. of Env. and Earth Sci. $2225-0944,9$.

Fitch, P.J.R., Jackson, M.D., Hampson, G.J., and John, C.M., (2014). Interaction of stratigraphic and Sedimentological heterogeneities with flow in Carbonate ramp reservoirs: impact of fluid Properties and production strategy. Petro. Geosci. 20, 7-26.

Gingras M.k., Pemberton S.G., and Saundners, T. (2001) bathymetry, sediment texture and substrate cohesiveness; their impact on modern glossifungites trace assemblages at Willapa bay, 
Washington. Palaeogeography, Palaeoclimatol and Palaeoecol 169, 1-21.

Gluyas, J. and Swarbick, R. (2004). Petroleum geoscience. Oxford: Blackwell Publishing co, 40252

Heinio, P. and Davies, R.J. (2006). Degradation of Compressional Fold Belts: deep water Niger delta: AAPG bulletin, 90, $753-770$.

Hooper, R. J., Fitzsimmons, R. J., Grant, N. and Vendeville, B. C. (2002). The role of Deformation in controlling depositional patterns in the southcentral Niger delta, West Africa: Jour. of Struct. Geol, 24,847-859.

Keele, D. and Evans, J. (2008). Analysis of reservoir Properties of faulted and fractured eolian thrustbelt Reservoirs. Utah Geological Survey.

Lawrence, S.R., Munday, S.and Bray, R., (2002). Regional geology and geophysics of the eastern Gulf of guinea (Niger Delta to Rio Muni): the leading edge, 21, 1112- 1117.

Mac Eachern, J.A. and Gingras, M.K., (2007). Recognition of brackish-water trace-fossil suites in the cretaceous Western interior seaway of Alberta, Canada; Sepm Spec. Publ., 88, 149.

Okengwu, k. O. and Amajor, L. C., (2014). Lithofacies and depositional environment Study of the "A1" reservoir sand, well-5, Boga field, Niger Delta, Nigeria. Inter. Journ. of Eng. Sci., and Manag.4, 76-93.

Oomkens, E. (1974). Lithofacies relations in late Quaternary Niger Delta complex: Sedimentology, $21,195-222$.

Pochat, S., Castelltort, S., Vanden D. J., Besnard, K., and Gumiaux, (2004). A simple method of determining sand / shale ratios from seismic analysis of growth faults: an example from upper oligocene to lower miocene niger delta deposits: AAPG Bulletin, 88, 1357 - 1367.

Readings, H. G., (1996). Environment of deposition of source beds of high-wax oil. AAPG,Bulletin, 53, 1502-1506.

Reineck H.E and Singh I.B. (1980). Depositional sedimentary environments. Springer, Berlin, 551.
Rider, M.H., (1996). The Geological Interpretation of Well Logs. Caithness, Blackie, Glasgow, Scotland. (2 $\left.{ }^{\text {nd }} \mathrm{Ed},\right)$. 151-165.

Selley, R.C. (1978). Concepts and methods of subsurface Facies Analysis. AAPG Contin. Educ. Course note series, 9 .

Serra, O. (1985). Sedimentary Environments from wire line logs. Schlumberger Publications, 243.

Serra, O. and Sulpice, I. (1975). Sedimentological analysis of shale-sand series from well logs. SPWLA, 16.

Slatt, R.M. (2006). Stratigraphic reservoir characterization for petroleum geologists, geophysicists and engineers. Elsevier Science, 1, 492.

Snedden, J.W. and Bergman, K.M. (1999). Isolated Shallow marine sand bodies, deposits for all Interpretations. SEPM special publication, 1-11.

Stacher, P., (1995). Present understanding of the Niger delta hydrocarbon habitat, in, Oti, M.N., and Postma, G. Geology of Deltas, 257-267.

Short, K. C. and Stauble, A. J. (1967). Outline of geology of Niger Delta: AAPG,Bulletin, 51, 61779 .

Tuttle, M. L., Charpentier, R. R. and Brownfield M. E. (1999). The Niger delta Petroleum system: Niger Delta province, Nigeria, Cameroon, and Fquatorial Guinea, Africa. USGS open-file report, 99-50.

Walker, R.G., and Plint, J.N., (1992) Facies Models: Response to Sea Level Change. Love Printing Service LTD. Stittsville, Ontario.

Weber, K.J (1971). Sedimentological Aspect of Oil Fields in the Niger Delta. Geol mijnbouw, 50, 559576.

Weber K.J, Daukoru E. M. (1975). Petroleum Geology of the Niger Delta Procninth World Petrol. Congress, 2, 209-221. 